PP-015

\section{MOOC TRAINING?: A WAY FOR CONTINUING EDUCATION OF} FAMILY MEDICINE

Özden Gökdemir ${ }^{1}$, Nurşah Özkan², Candan Kendir ${ }^{3}$, Olgu Aygün ${ }^{4}$, Kyle Hoedbocke ${ }^{5}$

${ }^{1}$ Izmir University of Economics-Medical Faculty, Izmir, Turkey

${ }^{2}$ VKV American Hospital, Istanbul, Turkey

${ }^{3}$ Ecole des hautes etudes en sante publique (EHESP), Saint-Denis, France

${ }^{4}$ Paslanmaz Family Healthcare Center, Nevşehir, Turkey

${ }^{5}$ Yongsan Health Clinic, Seoul, South Korea

Background: Massive open online courses (MOOC) is a web-based application to transform the whole world into a school environment. In this way, the quality of education could be raised without discrimination. In 2018, 66 Family Practitioners and trainees attended the "Improving Global Health: Focusing on Quality and Safety" program simultaneously. The goal was to benefit from visual and written education tools from different countries and different age groups. The aim of this study is to evaluate the benefits and/or educational needs after this MOOC.

Materials and Methods: Sixty-six family medicine practitioner and trainees were the universe of the study. Due to the international participants; the survey was conducted in English online to the group. Results: Twenty-seven participants have answered the survey. Most of them were female $(70.4 \%)$, young family physician $(92.5 \%)$ and haven't attended to any MOOC course before $(63 \%)$. The age of the participants were min:31years max:49 years. They do want to attend the upcoming MOOC courses. Only 2 of them didn't have any opinion about the contribution of the MOOC courses to primary care services. They feel that group activity is much more beneficial because they wouldn't be faster, more interested in or motivational. One of the half structured qualitative survey answers was "although I would enjoy a face to face work, this course is the opportunity to include countries that today are in crisis and it would be impossible to face the cost of education under another modality".

Conclusions: Well defined and structured MOOC could be more beneficial with motivational group dynamics. This option qualifies the health and health education.

Key words: quality, education, online courses, family medicine, quantitative

\section{PP-016 \\ ANALYSIS OF A FREE-CHOICE ELECTIVE COURSE 'WHAT WILL HAPPEN WHEN YOU GRADUATE FROM MEDICAL SCHOOL?'}

Cevval Ulman ${ }^{1}$, Suheyla Rahman ${ }^{2}$, Nuran Ekerbiçer ${ }^{3}$

${ }^{1}$ Manisa Celal Bayar University, Faculty of Medicine, Dept. of Medical Biochemistry, Manisa, Turkey

${ }^{2}$ Manisa Celal Bayar University, Faculty of Medicine, Department of

Medical Education, Manisa, Turkey

${ }^{3}$ Manisa Celal Bayar University. Faculty of Medicine, Department of

Physiology, Manisa, Turkey

Background: Manisa Celal Bayar University Faculty of Medicine Preclinical Elective Program was introduced in 2010 for broadening the learning of its undergraduate students. The medical elective course evaluated herein is named as 'what will happen when you graduate from medical school?'. The purpose of this study is to analyze medical student's ideas with a view of better understanding the factors that influence their choices and their needs.

Materials and Methods: In this preliminary study, 12 medical students' feedback forms who took the elective course in year 2017-2018 were evaluated retrospectively. The forms evaluated had demographic questions, a question about why this course was chosen, and 5 likert type questions.

Results: Five Male and seven female students, 6 first year and 6 second year students filled in the forms. All Participants indicated that the elective to include first and second year students in the same class made a contribution in interactivity. Participants described that they are happy to take the course from the professor giving it, the course day and hour is appropriate, and the course contributed to a great extend for medical education and afterwards.
Conclusions: Our investigation revealed that medical students tend to focus on usefulness of the topic and the professor giving it. Students have an interest in the subjects such as future of Medicine, communication, sign language and robotics etc. We believe free-choice elective courses are necessary, good for communication in small groups and topics with student interest need to be included in the programs. Keywords: Medical students, Undergraduate, Elective program, Elective choices, Student motives

\section{PP-017}

GRADUATE EDUCATION AT KOC UNIVERSITY GRADUATE SCHOOL OF HEALTH SCIENCES (GSHS): AN EMPHASIS ON REPRODUCTIVE MEDICINE

Serçin Karahüseyinoğlu

Koç University, School of Medicine, Dept. of Histology \& Embryology, Istanbul, Turkey

Background: As graduate education is considered, each discipline may need a different type of educational approach for the accomplishment of successful outcomes. The objective of this informative revision is to reveal a variety of approaches in education and training at Koç University GSHS, with a closer look on reproductive medicine programs. Overlook: KU-GSHS has 12 programs, including the joint ones, and there are $\mathrm{MSc}$ and $\mathrm{PhD}$ programs related to area of reproductive sciences. MSc for reproductive biology was started in 2011 and PhD for reproductive medicine was implemented in the year 2016.

Management: For MSc program, candidates from biological sciences (biology, molecular biology and genetics, bioinformatics and genetics) and for $\mathrm{PhD}$ training students that have a prior education in a variety of biological sciences (medicine, MBGE, histology \& embryology, etc) are selected. The programs accept students only for full-time positions, and tuition fee is covered by grants or the institute. The students are responsible for active involvement in development and maintenance of research projects. The didactic curriculum covers a wide range of specific topics (basics of reproduction and IVF). Students can also take all types of courses given at the institute. Hands on trainings include wet lab techniques (cell culture, molecular techniques, advanced microscopy) and specific techniques related to IVF area (gamete and embryo manipulation, micromanipulation, 3D cultures systems). Graduates are able to find post-doc positions in reproduction area. Specific hands on trainings, enable them to be accepted for clinical embryology programmes in institutes throughout the world.

Conclusion: Graduate education occasionally may involve a major "hands on training" approach, rather than didactic approaches.

\section{PP-018}

\section{APPLYING TEAM-BASED LEARNING FOR THE INTEGRATION OF BASIC MEDICAL DISCIPLINES ON TOPC "THE CELL:" A PILOT EVALUATION}

Gül Güner Akdoğan ${ }^{1}$, Melis Yandım Kartal ${ }^{1}$, Yasemin Seval Celik ${ }^{1}$, Banu Demir $^{1}$, Ali Burak Özkaya ${ }^{1}$, Sevinç İnan ${ }^{1}$, Hakan Abacıoğlu' ${ }^{1,2}$

${ }^{1}$ Division of Basic Medical Sciences, School of Medicine, Izmir University of Economics, Izmir, Turkey

${ }^{2}$ School of Medicine, Izmir University of Economics, Izmir, Turkey

Background: Team-based learning (TBL) is a structured method of smal group learning that can be implemented for a variety of purposes. TBL has become widely applied in medical schools and its use is typically limited to certain courses or parts of courses. In our study, we applied the TBL for a different purpose: integrating and reviewing the main concepts about "the cell", learned within a basic medical course. This presentation describes the experience on applying TBL at the end of the semester course, "Scientific Basis of Medicine", dealing mainly with the cell and cellular activities as a pilot study. The course was held for the first year students of the School of Medicine of Izmir University of Economics, during the 2017-2018 fall semester. This medical school admitted its first students in 2017. The new undergraduate medical programme, developed collaboratively by faculty from the different fields of basic and clinical medical sciences involves interactive lecturing and other student centred activities within an e-learning ecosystem as its main learning and teaching strategy. One of the student-centred activities is the TBL. 